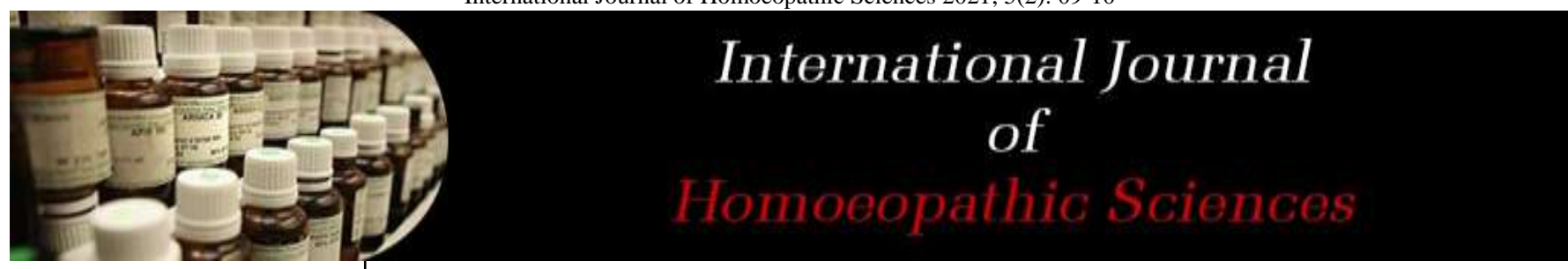

E-ISSN: 2616-4493 P-ISSN: 2616-4485 www.homoeopathicjournal.com IJHS 2021; 5(2): 09-10

Received: 07-01-2021

Accepted: 10-02-2021

Dr. Siddhesh Ramakant Ranade

Md Hom, Department of Homoeopathic, Materia Medica, Shelgaon, Jalna, Maharashtra, India

Dr. Shankar Huleka College Guru Mishri, Homoepathic Medical College, Shelgaon, Jalna, Maharashtra, India
Corresponding Author: Dr. Siddhesh Ramakant Ranade

Md Hom, Department of Homoeopathic, Materia Medica, Shelgaon, Jalna, Maharashtra, India

\title{
Common skin disease "corns" with effective homeopathic medicine Silicea
}

\section{Dr. Siddhesh Ramakant Ranade and Dr. Shankar Hulekar}

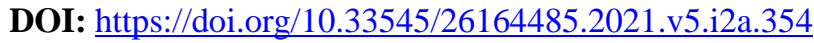

\begin{abstract}
A corn (also termed clavus) is a thickening of the skin due to intermittent pressure and frictional forces. These forces result in hyperkeratosis, clinically and histologically. The word clavus has many synonyms and innumerable vernacular terms Silicea is a good homeopathic remedy of many skin issues one of from it corns. Silicea helps the body eliminate splinters, acne, eruptions, corns, and fungus issues. It also indicates in keloidal growth, felons, abscesses, boils, old ulcers. Silicea is key roll medicine in homoeopathic Materia medica in skin region. In India corns (clavus) are very commonly found. It will help to explore the scope and therapeutic effect of silicea in management of corns.
\end{abstract}

Keywords: Awareness, corns, useful homoepathic medicine silicea

\section{Introduction}

Corns are one of the most common foot conditions in particularly amongst older patients. It is a common disorder because of the frequency of usage of occlusive footwear and mostly in activities such as running. Corns are common worldwide. Any human with weight-bearing is susceptible to the development of corns.

An epidemiological study evaluating the prevalence of foot conditions amongst a diverse sample of adults from the north eastern United States revealed a significant difference in rates of corns amongst ethnic groups. African Americans had a significantly higher rate of corns and calluses compared with non-Hispanic white and Puerto Rican participants (70\% vs $58 \%$ vs $34.1 \%$ ) The Extrapolated statistics of Corns and calluses in India is 26,626,765 per $1,065,070,607$ populations estimated.

In elderly populations, both men and women have been reported to wear shoes too narrow for their feet. Women have been reported to wear shoes that are also shorter than their feet. Both narrow as well as short footwear may lead to the development of corns, in addition to foot deformities. They are most common in women than in men because of this use of occlusive and badly fitted footwear.

Hyperkeratotic lesions of the foot (including corns and calluses) have been reported to affect $20-65 \%$ of people aged 65 or older.

Corns can be easily managed under the Homeopathic mode of treatment that uses a very gentle approach. These remedies for corns are very effective and attack the problem at the root. Removing the corns with surgery also carries the risk of infection, while natural medicines provide a permanent and completely safe solution to corns. Antimonium Crudum, Hepar Sulph, Silicea, Nitric Acid, Lycopodium and Ranunculus Bulbosus are mostly used in treatment of corns.

Silicea is another of the top-grade medicines for corns. It is seen excellent results in patients with soft corns with the use of Silicea, which is natural and therefore, safe. Soft corns mainly appear between the toes. Silicea is one of the most effective. sore and painful corns are mostly characteristic. Silicea very nicely works in cases of corns between toes that tend to suppurate (discharge pus). Excessive sweat with an offensive odor may be present on the foot where the corn is located. 


\section{References}

1. Mann RA, Pain in foot 1. Evaluation of foot pain and Identification of associated problems Post Grad Med 1987;82(1):154-7, 160-2

2. Dunn JE, Link CL, Felson DT, Crincoli MG, Keysor JJ, Mc Kinlay JB. Prevalence of foot and ankle conditions in a multi ethnic community sample of other adults. Am J Epidemiol 2004;159(5):491-8.

3. Menz HB, Morris ME. Footwear characteristics and foot problems in older people. Gerontology 2005;51(5):346-51.

4. Black JR, Hale WE, Prevalence of foot complaints in the elderly. J Am Podiatr Med Assoc 1987;77(6):30811.

5. Richards RN. Calluses, corns, and shoes. Semin Dermatol 1991;10:112-4.

6. Williams ML, Reddy E, Sharma PK, Raj PP. A clinical study on effect of Plantago in gingivitis by assessing bleeding and plaque index 269-73

7. Singh D, Bentley G, Trevino SG. Callosities, corns Ans calluses. BMJ 1996;312(7043):1403-6.

8. Hirao M, Ebina K, Shi K, Tomita T, Noguchi T, Tsuboi $\mathrm{H}$, et al. Association between preoperative pain intensity of MTP joint callosities of the lesser toes and fore-mid-hindfoot deformities in rheumatoid arthritis cases. Mod Rheumatol 2017;27(1):50-53. [Medline].

9. Patruno C, Napolitano M, La Bella S, Ayala F, Balato $\mathrm{N}$, Cantelli M, et al. Instrument-related Skin Disorders in Musicians. Dermatitis 2016;27(1):26-9. [Medline

10. Goksugur N, Cakici H. A new computer-associated occupational skin disorder: Mousing callus. J Am Acad Dermatol. 2006;55(2):358-9. [Medline].

11. Cox NH, Finlay AY. Callosities of crossed-leg sitting. Int J Dermatol 2009;48(11):1266-7.

12. Murphy GA. Lesser Toe Abnormalities: Corns (Helomata and Clavi). Canale ST, ed. Canale: Campbell's Operative Orthopedics. $10^{\text {th }}$ St. Louis, Mo: Mosby 2003. 4063-5.

13. Coughlin MJ, Kennedy MP. Operative repair of fourth and fifth toe corns. Foot Ankle Int. 2003;24(2):147-57. [Medline

14. Menz HB, Zammit GV, Munteanu SE. Plantar pressures are higher under callused regions of the foot in older people. Clin Exp Dermatol 2007;32(4):375-80. [Medline]

15. Verbov JL, Monk CJ. Talar callosity--a littlerecognized common entity. Clin Exp Dermatol 1991;16(2):118-20. [Medline]

16. Oztekin HH, Boya H, Nalcakan M, Ozcan O. Secondtoe length and forefoot disorders in ballet and folk dancers. J Am Podiatr Med Assoc. 2007;97(5):385-8. [Medline]

17. Baccouche D, Mokni M, Ben Abdelaziz A, Ben Osman-Dhahri A. [Dermatological problems of musicians: a prospective study in musical students]. Ann Dermatol Venereol. 2007;134(5 Pt 1):445-9. [Medline].

18. Gambichler T. Reddy SR. Effect of homoeopathic medicine Lycopodium clavatum in urinary calculi. International Journal of Applied Research 2017;3(1):790-1. [Medline]

19. Verma SB, Wollina U. Callosities of cross legged sitting: "yoga sign"--an under-recognized cultural cutaneous presentation. Int J Dermatol
2008;47(11):1212-4. [Medline].

20. Darvall WA. Flash dancing and spine bumps. Med J 1984;28-140(9):568. [Medline].

21. Lemont H, Ravick A. Hemorrhage within plantar callus. A cutaneous sign of rheumatoid angiitis. J Am Podiatry Assoc 1980;70(1):22-5. [Medline]

22. Murray HJ, Young MJ, Hollis S, Boulton AJ. The association between callus formation, high pressures and neuropathy in diabetic foot ulceration. Diabet Med 1996;13(11):979-82. [Medline]

23. Snider RK. Corns and Calluses. Greene WB, ed. Essentials of Musculoskeletal Care. 2nd ed. Rosemont, Ill: American Academy of Orthopedic Surgeons 2001, 437-41.

24. Farndon L, Concannon M, Stephenson J. A survey to investigate the association of pain, foot disability and quality of life with corns. J Foot Ankle Res 2015;8:70. 